\title{
DEVELOPMENT OF A PRODUCT AUDIT TOOL
}

\author{
James MOULTRIE \\ Institute for Manufacturing, University of Cambridge, Mill Lane, Cambridge, CB2 1RX, UK \\ jm329@eng.cam.ac.uk \\ P John CLARKSON
}

Head of the Engineering Design Centre, Department of Engineering, University of Cambridge

\section{David PROBERT}

Head of the Centre for Technology Management, Institute for Manufacturing, Department of Engineering, University of Cambridge

\begin{abstract}
The creation of new products that satisfy the needs of customers and the company is widely acknowledged as an important contributor to a firm's ongoing success. In principle, the design process, as part of the wider new product development (NPD) process, should result in products that are 'well-designed'. But, what does a well-designed product look like?

This paper presents a tool to enable a design team to evaluate their products against a range of criteria, with a view to targeting design improvements. This 'product-audit' tool is based on literature and has been iteratively developed using a mixed research approach, including detailed exploratory cases and application in action research mode.

Previous assessment tools have tackled a narrow set of product issues, such as usability. This tool addresses the 'whole product' and captures aspects of product design in a concise and usable form. The product audit does not seek to be a benchmarking tool. Aspects such as novelty, desirability, usability and producibility are expanded as simple checklists, to enable perceptions towards product characteristics to be assessed.

This novel assessment tool encourages greater consideration of design issues within the wider context of NPD. By focusing attention on the tangible output of the design process - the product - practitioners are better able to understand the way in which design decisions influence product usability, desirability and producibility. Case evidence confirms both the value and originality of this tool.
\end{abstract}

\section{KEYWORDS}

Design audit tool, design process, product 


\section{INTRODUCTION}

There is compelling evidence that 'good design' is a significant source of competitive advantage, both in markets with mature products and for highly innovative technologies [1-5]. However, despite the importance creating effective products, many Small \& Medium Sized Enterprises (SMEs) face specific challenges in the design of new products. Critical design-related activities are often poorly performed in SMEs [6]. Resource limitations and perceived barriers to involving external specialists result in 'silent design' [7, 8] where engineering or marketing staff undertake aesthetic and ergonomic design work themselves [9]. This principle can be extended to include other market and user focused elements of the design process; 'silent marketing' [4]. Furthermore, the emphasis on managerial aspects of the product development process (including time to market, project spend, risk reduction and unit cost [10-12] reduces the emphasis on creating products which are designed effectively. It is often the case that highly efficient processes result in products which are difficult to use, look terrible and are costly to manufacture. Thus, as companies gain improved control over selecting and managing projects, attention must focus on the delivery of high quality products. Several new product development success factor studies conclude that success is contingent on the creation of superior, clearly differentiated, unique and 'well-designed' products [e.g. 13-16]. But, what exactly does a well designed product look like?

This paper describes the development of an audit tool to enable practitioners in SMEs to assess the design of their products and to raise awareness of good design issues. This 'product audit' tool forms one half of a wider approach to enhancing design capability in SMEs. The other half - the 'process audit' - addresses the product design process. The combined audit tool integrates perspectives from a wide range of sources and has been developed iteratively in over 20 firms. Following a brief overview of the research approach, literature underpinning the product audit is described in detail. The audit tool itself is then described, followed by two short case examples. Wider implications for practice and theory are then discussed.

\section{RESEARCH APPROACH}

The product audit was developed in parallel to the creation of a 'maturity' based audit tool directed at the design process. The combined product and process audit tool was developed iteratively, following an applied research methodology, through four phases of exploration, tool development, tool application and reflection [17]. This applied approach was appropriate, given the human nature of product design [18] and was consistent with the broad goals of deign research; to develop understanding about the phenomenon of design, whilst also seeking to improve the chances of producing a successful product [19]. The four phases are briefly described below, and a full list of cases is provided in Table 1.

- Phase 1 - exploratory study: literature and four longitudinal exploratory cases confirmed the need for an improved awareness of good design issues and provided rich input to the 
generation of a pilot audit tool. Data was captured through regular progress meetings, anecdotal observations, project documentation and a semi-structured interview at the end of each project.

- Phase 2-tool creation and feasibility: a prototype audit tool was developed and evaluated (semi-structured interviews with six industrialists) for errors of omission, commission and organisation of information. The tool was then applied in three cases, following an action research approach [20] to establish its feasibility [21], usability and utility [22]. Multiple data sources were used, including verbal feedback from participants, structured questionnaires, post-workshop reviews, and independent researcher observation.

- Phase 3-tool development: a modified audit tool was applied in a further three companies and again evaluated for feasibility, usability and utility.

- Phase 4 - validation: to establish wider validity, ten industrialists reviewed the audit tool. Respondents were given a copy of the design audit (in the form of a 'workbook') and asked to make comments. Results from semi-structured interviews and written feedback were incorporated into a final version of the audit tool.

\section{TABLE 1 ABOUT HERE}

During this development cycle, the design audit progressed through 3 substantial revisions affecting the underlying architecture of the tool, with over 40 smaller modifications to individual details including activity descriptions, graphical layout and delivery procedure.

\section{LITERATURE}

Since the 1960s, there have been over 50 studies which have aimed to establish the factors which lead to success in New Product Development (NPD). Many of these studies have cited productrelated factors, including "advantage over the competition" [16], "technical superiority [23, 24], "clear benefits" [13] and "product uniqueness or novelty" [14, 15, 25]. In many ways however, these factors are somewhat unhelpful. Clearly superiority is important, but what are the product characteristics that generate this superiority? Lorenz [26] argued that conventional means of differentiation (cost and quality) are now 'entry tickets' and that product appearance and character are increasingly the key to producing meaningful differentiation. Nixon [27] specifically mentions the relative importance of product aesthetics as a primary differentiator in crowded market segments. Rutter \& Agne [28] interviewed 80 people in an attempt to understand consumer attitudes towards 'good design' and conducted a 500 person survey to investigate the design of computers. They determined that people expect products to "work well and look good"; where working well is a price of entry and enables the task to be executed with ease.

A more structured way of viewing a product is as a complex, multi-layered set of attributes - the 'design mix' [26, 29]. This design mix must provide some "core benefits" to the user that are 
embodied in the "actual product" (e.g. form, function, quality and realisation) [30-32]. The actual product is "augmented" by a range of product related services (e.g. finance deals, servicing and installation). Finally, the product's underpinning business model forms the "meta-product" [33, 34]. This "meta-product" represents the underlying strategy supporting the product: for example, the Apple iPod is successful in part because of its unique business model, linking the hardware with software and the availability of media to purchase online. Firms should thus seek to address all of these aspects of this design mix when creating new products - but which elements are most important and what are the product characteristics that relate to each?

Bloch [35] determined a correlation between the receipt of design awards and commercial success. Thus, the judging criteria of 17 major international design awards were reviewed to identify consistent themes and the results are summarised in table 2. Usability and desirability receive most attention, with product utility (including elements of functionality or fitness for purpose) a close second. These attributes are also widely supported by authors in design and related domains (also summarised in table 2). There is general consensus on the need to deliver strong core benefits and greatest agreement over the importance of product appeal, and usability. Perhaps surprisingly, the augmented and meta-product attributes receive relatively little attention.

Thus, building on Kotler's [5] multi-layered model, a generic set of attributes was identified to form the underpinning architecture of the product audit (table 2). By selecting these characteristics, it is not the intention to claim that this is a definitive description of 'good design'. However, it is representative of a holistic approach to design and is thus appropriate for use in this context. The elements of each of these characteristics will now be described in more detail.

\section{TABLE 2 ABOUT HERE}

\section{CORE BENEFITS}

There are many ways in which a product might provide benefits to its users. Purely utilitarian devices seek to perform a task efficiently. Decorative items offer little practical functionality but provide benefits in more subtle ways. The inherent need for a product is easiest to establish when a product delivers practical results both efficiently and effectively. Need is harder to qualify for non-practical devices whose purpose is mainly decorative. Whilst it is therefore difficult to assess a product's core benefits, it is still possible to identify a number of contributing factors. Effective products have appropriate functionality, and avoid the pitfalls of excess or insufficient capability [32]. Functionality is most likely to be judged against the availability of viable alternatives which provide consumers with a similar set of benefits. A lack of genuine substitutes is indicative of clearly differentiated benefits [29]. Finally, a product's perceived value can be viewed as the degree to which customers are willing to pay a premium for a product beyond the direct rewards of its functionality [51, 52]. 


\section{PRODUCIBILITY}

The terms producibility, manufacturability and design for assembly were introduced in the 1960s [48]. The general goal of all Design for Manufacture (DfM) methods is to reduce the overall manufacturing cost [53]. DfM approaches can be applied at a component, sub-system (product or assembly) or system (product family) level. At a system level, the goal is to optimise the overall production system, reducing component count across the business [54]. At a sub-system level, the goal is to optimise a sub-assembly for production [55]. At a component level, the aim is to optimise the manufacturing process for an individual part [48].

\section{Optimising the system: platforms \& modularity}

Design for manufacture principles are typically applied to individual products (or assemblies) at a single point in time [56] and normally encourage sub-system optimisation to minimise the number of components. Such approaches are sensible at the sub-assembly level, but can result in individually complex components which cannot be re-used across other products [49]. This situation is exacerbated when new products are developed with little reference to prior products [50]. The result is a proliferation of unique components, each requiring manufacture, purchase and storage. One way to address this is to reuse technology, parts and processes with a product platform approach [49], which seeks to provide customers with the maximum product variety, whilst minimising the production complexity within the business [57]. Product platform planning requires a systematic consideration of markets and available technologies to identify those which can form the basis of different product offerings for different market segments [50]. It is thus a strategic issue, which demands consideration early in the design process. Technology reuse is enabled by the creation of modular product architectures, where a module can be defined as a 'unit whose structural elements are powerfully connected among themselves and relatively weakly connected to elements in other units' [58]. Modular subsystems enable both change (e.g. upgrade, add-ons, replacements etc) and product variety. Products which need to be optimised (e.g. for speed, weight, size etc) generally benefit from a highly integrated architecture. Platform strategies and modularity have both positive and negative cost implications and thus need approaching from an economic (and not a philosophical) perspective [49].

\section{Optimising the sub-system: design for assembly}

Design for Assembly (DfA) is a major subset of any DfM approach [48]. DfA methodologies typically seek to minimise the overall complexity of an assembly, whilst maximising the ease with which parts can be held, located and joined. There are two basic approaches to considering DfA; systematic methods and heuristic guidelines.

Systematic approaches provide a repeatable process to analyse and improve a sub-assembly. The best known are the Boothroyd \& Dewhurst method developed in the 1970s and the Lucas Engineering \& Systems method developed in the 1980s [48, 59]. They both follow a similar 
approach to analysing an assembly (functional analysis, handling analysis, insertion analysis, joining analysis, secondary operations and assembly mapping) [59]. Judgements are made by the design team, with assessment based on (sometimes software enabled) data tables which provide a relative measure of design effectiveness and an indication of the overall assembly efficiency.

There are many heuristic guidelines for DfA, which aim to provide designers with a short soundbite of good practice. These guidelines are often presented graphically, with an example of 'poor design' followed by suggested improvements. Otto \& Wood [59] identified 20 common DfA guidelines including; minimise part count; designing out wires and cables; design out adjustment; maximise part symmetry; insert parts from the same direction; insert parts from above; eliminate fasteners; and do not assemble in enclosed spaces.

\section{Optimising the component: design for manufacture}

Having optimised the system (product range) and the sub-system (the product or assembly) the last concern is to optimise the individual components. Whilst the term DfM is often used widely to encompass all three elements, it is perhaps most accurately used more narrowly to encompass the latter. Thus, many DfM principles specifically seek to support component optimisation. Firstly, the right process needs to be selected [53]. Secondly, efforts should be made to reduce process stages, and specifically eliminate finishing processes [56]. Finally, the component must be optimally designed to take advantages of the specific process. There are numerous volumes of guidelines addressing individual processes in detail [e.g. 48] and are thus beyond the scope of this work.

\section{DESIRABILITY}

It has been claimed that given the choice between 2 products equal in price or function, consumers will buy the one they consider most attractive [5, 35, 60]. Stylistic and aesthetic aspects are clearly dominant influences on a consumer's desire for a product $[27,28,35,39]$. The way a product looks and feels is fundamental to the generation of positive emotional responses, or 'affect' from the consumer [9, 61, 62]. Positive affect tends to result in approach behaviours (e.g. purchase), whilst negative affect is evident through avoidance behaviours (e.g. hiding it from view) [35]. A desirable product could be said to be one which induces approach behaviour from its intended audience.

Reactions towards a products appearance can be decomposed into three distinct classes [47]. The way a product looks will result in consumer judgements about its underlying elegance, or aesthetics [63]. Through interpreting semantic information, consumers also make judgements about functionality or fitness for purpose [34]. Finally, the product's social or symbolic significance is also largely influenced by appearance [64].

\section{Aesthetics}


The term aesthetics is most commonly used in relation to visual appearance and is often restricted to the discussion of perceived attractiveness [65]. A consumer's aesthetic impression is the sensation that results from the perception of attractiveness $[66,67]$ and consumers may perceive products as having an intrinsic attractiveness [68]. However, there is no coherent theory to explain the aesthetic aspect of design [69], although there are a number of well-established aesthetic principles.

Early scholars of beauty believed that attractive features resided in the object itself [70] and thus certain lines, proportions, shapes and colours were considered inherently attractive [71]. A natural conclusion is that each object has an ideal form, which once attained would be considered attractive by all [63]. This belief in the inherent attractiveness of specific shapes is exemplified by the continuing usage of aesthetic rules established in Greek architecture; where the 'golden rectangle' [72] was believed to be more attractive than rectangles of other dimensions. In the 1920s, the Bauhaus school pioneered a highly rational design philosophy founded on a belief in the existence of such fundamental principles (or Gestalt Rules) which if followed would result in beautiful products $[68,73]$. These rules emphasise symmetry, proximity, regularity, and pattern repetition to create a visual 'harmony' $[63,74]$ and are now generally discredited by mainstream psychology. Furthermore, there is also evidence to suggest that oversimplification leads to visual monotony [68].

Berlyne [75] suggested that attractiveness results from a balance between simplicity (or harmony) and complexity [70]. Berlyne concluded that attractive products combine both the familiar (providing reference points) and the unfamiliar (demanding attention and exploration). Several authors have expressed product attractiveness as a balance of opposing factors [e.g. 63, 76, 77]. Coates [63] proposed that products must balance arousal (through the provision of contrast and novelty) against meaning (through the provision of inherent visual order and sense) to be attractive. In addition, perceptions may change over time, and what seemed attractive at first may later appear dull and unexciting [68].

\section{Semantics}

Product semantics can be thought of as 'what the product says about itself'; its function, mode of use and qualities. Crozier [66] uses the term 'semantics' to refer to the communication of a product's utilitarian values and practical benefits. In addition to communicating utilitarian values, a product's semantic information can also communicate more general visual values, such as speed, weight, strength or age $[67,68]$. Thus, a product's appearance may convey distinct messages by either expressing specific qualities (such as density, stability, fragility etc) or by adopting anthropomorphic characteristics to suggest dynamism, stability or even facial characteristics [34, 78-80]. Furthermore, the product's appearance may also provide visual clues as to its origins, predecessors, affiliation and brand characteristics. By enabling clear identification viewers may experience 'prior knowledge attractiveness' [34, 68]. 


\section{Symbolics}

In addition to practical and decorative qualities, products also hold some socially determined symbolic meaning [81]. These culturally established meanings enable a person to communicate their identity through objects to express their social status [64] and thus, products contribute to an individual's 'expressive equipment' [82]. For example, a chair can be said to denote (or afford) sitting, while a throne connotes (or implies) power and status [83]. A product's symbolic values are often influenced by its context of use and the object's relation to other artefacts. Dittmar [64] divides the symbolism of material possessions into both self expressive (expresses a unique aspect of the user's personality) and categorical (expresses group membership) meanings.

\section{Consumer response}

Response to product appearance results from a combination of aesthetic response, semantic interpretation and symbolic associations. In practice of course, these three components are inextricably linked. Lewalski [74] noted that a product can be considered attractive when it appears to promise the satisfaction of human needs (semantics) and makes the distinction between visual responses that are instinctive (aesthetics) and those that are learned (symbolism or meaning). Based on our interpretations of a product's appearance, performance and function, an emotional response is aroused in the consumer. Jordan [46] categorises four modes of emotional response (four pleasures); physiological, ideological, sociological and psychological. Ideological pleasure may result from the satisfaction of basic 'values' such as environmental concerns or aesthetic preference. Sociological pleasure is derived from the social meaning attached to products. Physiological pleasure may result from a tactile control, comfortable surface or reassuring noise. Finally, psychological pleasure is gained when the product works as intended to address the task in hand [46]. Sociological and ideological pleasure can be closely associated with the product's aesthetic and symbolic expression. Physiological and psychological pleasure however relate more closely to the usability and comfort associated with the product.

\section{NOVELTY \& DIFFERENTIATION}

Successful products normally exhibit novelty along one or more dimensions $[14,15,25]$. Utterback [16] noted that successful products must have "advantage over the competition in a key aspect and moderate advantage in several aspects". This commercial advantage is achieved through clear product differentiation, defined by Kotler et al [29] as a "sustainable internal or external strength ... over competition". Novelty and differentiation can be considered as different sides of the same coin. Consumers desire novelty, whilst companies seek to produce clearly differentiated offerings. It is possible to offer differentiated offerings for each element of the design mix. In an ideal case, a product would provide clearly differentiated core benefits, solving problems which have not previously been addressed. However, it is more likely that products are differentiated through their actual properties, including aesthetics, ergonomics or technical 
performance. Products can also be differentiated through their supporting services or even their underlying business model.

\section{USABILITY}

Product usability is widely recognised as a critical dimension of product quality which is increasingly important commercially [46]. Unfortunately, many design processes still result in products which fail to meet the expectations of users [36]. But, what exactly is usability and how do we assess the usability of products?

The word ergonomics was derived in 1949 by Professor Murrell from the Greek "ergon" meaning work and "nomos" meaning natural laws. Ergonomicists were originally concerned with the "study of human beings in their working environments" [84]. Most early ergonomics research was focused on the measurement of the human body. In the post war period, the U.S. army began a programme of 'human engineering' and issued standards for the design of military equipment based on measurements of adult males available for military service. In the 1960s, there was further systematic measurement and data collection on the size of adults and by the 1970s, the automotive industry extended the survey to include children and infants. Through the 1980s and 90s, other portions of society were also measured, including the elderly. Thus, ergonomics can now be viewed as encompassing the physical fit between people and products [45], in terms of an object's size, shape, position and force relative to the size, shape, position and effort required for comfortable use. This is more frequently referred to as anthropometrics; "the science of measurement and the art of application that establishes the physical geometry, mass properties, and strength capabilities of the buman body" [85].

Pheasant [84] suggests that an ergonomic design is one which has functional efficiency, is easy to use, is comfortable, improves the quality of working life and addresses health and safety concerns. However, simple statements such as 'ease of use' are insufficient to enable any practical assessment of a product's usability. Such generalisations result in many consumer goods being labelled (wrongly in most cases) 'ergonomically designed'. Babbar [36] suggests that usability provides a more "general term for ergonomic product quality" and Hennermann [86] claims that usability exists when "the design of the system matches what the intended users need and want it operates in the way expected."

In addition to the physical aspects of usability, it is also necessary to address the psychological and cognitive aspects of interacting with a product $[45,46,84,87]$. Cognitive usability is concerned with how information is processed and decisions are made and provides significant opportunities for product improvements; especially for software driven products, where the mode of operation is not instantly evident. 
Krippendorff [88] contends that "design is making sense (of things)" and that the designer should assist the user in correctly interpreting the product. This semantic approach to usability deliberately aims to foster communication between the object and user, though the provision of visual information to communicate intended function or mode of operation [89]. Thus, a product's appearance should describe its purpose and mode of operation and exhort an appropriate reaction from the user [34]. Norman [9] similarly describes the 'visual clues' which may improve the ease with which a product may be understood: 'affordances', 'constraints' and 'mappings' [9]. Other cognitive issues include the degree to which the operation of the system is easily learnt and remembered [36].

Recent work on inclusive design aims develops these principles further with a view to creating products which are sensitive to the capabilities of all users. This is consistent with Jordan's view that usability is not an inherent property of a product, but must always be considered alongside the capability of the user and the context of use [46, 90].

\section{TECHNICAL QUALITY}

Technical superiority is frequently cited as a key contributor to new product success [e.g. 13, 91]. Leading technical performance is a clear differentiator in both consumer and industrial markets, but can be difficult to sustain in the long run [28]. This attribute is likely to be of particular importance in niche markets and to early adopters [5]. Issues such as reliability, durability and build quality are more likely to be an order looser than an order winner when implemented poorly. Many products with leading performance along other dimensions fail due to poor quality implementation $[92,93]$.

\section{PROFITABILITY}

Product profitability is not evident to consumers but is of great importance to the company. Whilst not a direct product attribute, profitability can be measured objectively as a factor of sales price, unit cost, gross margin, contribution or market share.

\section{APPROACHES TO AUDITING PRODUCTS}

It is perhaps in the ergonomics domain that product assessment is most developed. Many approaches to assessing product usability are based around the objective assessment of product performance [94]; including goal achievement (e.g. accuracy and effectiveness), work rate (e.g. productivity and efficiency), knowledge acquisition (e.g. learning rate) and operability (e.g. error rate) [95]. Objective assessments can also be applied to other aspects of the design mix, including producibility (e.g. number of fasteners, unit cost). However, objective measures are less appropriate for intangible aspects such as desirability or for establishing perceptions towards issues such as usability [96]. Park \& Lim [94] suggest an alternative approach to product 
assessment based on general heuristics or 'rules of thumb'. These heuristics aim to capture the insight of experts [97] in a form which can be used by general practitioners. Such heuristics can be evaluated using a variety of approaches, including semantic differential scales or Likert based questionnaires [96]. Park \& Lim [94] for example provide a range of usability heuristics for software development. This latter approach was adopted for the product audit, to both enable evaluation of perceptions, whilst also being informative about principles of good design.

The simplest means of assessing an attribute is with a binary 'yes/no' response (figure 1 scale \#1). However, this provides little information about 'good practice' and offers little granularity when scoring. An alternative is to provide a Likert type scale, where the issue is posed as a positive statement and participants score the extent to which they agree (figure 1 scale \#2). Whilst providing greater granularity, there is still little insight into 'good-practice'. A third alternative is to adapt the Likert style questionnaire, to provide descriptive examples at different points along the scale. Han et al [96] followed this approach in a product usability audit (figure 1 scale \#3). This checklist is similar to a four point 'maturity scale' with anchor phrases at each point (figure 1 scale \#4). However, the intermediary descriptions provide little additional insight and it is challenging to create meaningful intermediate phrases. A final option is to use a modified "semantic differential scale", which seeks to establish the subject's perceptions towards the product [98]. Originally developed by Osgood in the 1950s [reference in 98], the semantic differential provides opposing descriptions at either end of a Likert type scale, typically using polar adjectives (e.g. hot - cold) [99]. This technique is commonly used in the assessment of visual product characteristics and results in a scale which captures the essence of the issue under consideration, with minimum repetition (figure 1 scale \#5). This approach forms the basis of the product audit.

\section{FIGURE 1 ABOUT HERE}

\section{THE PRODUCT AUDIT TOOL}

Combining evidence from exploratory cases and literature, a product audit tool was developed, structured around Kotler's [5] multi-layered model of the product. The emphasis of the tool has been placed on the physical aspects of the core product, with less focus on the augmented and meta product aspects. The overall architecture of the product audit is outlined in figure 2 .

FIGURE 2 ABOUT HERE

At each layer, key aspects of the product are developed in to a series of measurement scales, with anchor phrases at each end. The product audit enables a largely subjective assessment of perceptions towards the object. Modified semantic difference scales provide an appropriate way of capturing these perceptions by providing opposing descriptions of key characteristics. This 
approach enables 'good design' issues to be captured whilst being simple to score. An example worksheet is presented in figure 3 .

\section{FIGURE 3 ABOUT HERE}

In a company setting, a product audit workshop takes around half a day, involving a multifunctional team. There are 3 ways in which the results of the product audit are captured. Firstly, perceptions of current performance are mapped against perceived customer importance. Secondly, product strengths and weaknesses are captured and finally, proposed design improvements are recorded. The full product audit is reproduced in Appendix 1.

\section{SELECTED CASE EXAMPLES}

The complete design audit tool (product and process) was developed iteratively through application in 6 companies, with inputs from a further 20 companies. The application of the product audit in two of these cases is described below. These two cases were at the end of the research process and thus represent the use of the product audit in its final form.

\section{CASE O: SPECIALIST HI-FI (580)}

Company $\mathrm{O}$ designs and manufactures premium hi-fi systems for the audiophile. Over the last twenty years, they have been recognised as a technical market leader and have grown to employ around 30 people with a turnover of approximately $£ 3.5 \mathrm{~m}$. Their market has developed from a student market to an older audience with high brand loyalty. Competition has also become fierce, with improved product quality at the budget end, coupled with rapid technological changes. To maintain its market position, Company $\mathrm{O}$ values their distinctive aesthetics, excellent technical performance and first-class build quality. Following an approach to the Managing Director, the product audit was used in a workshop with 3 members of the senior team.

After a brief introductory presentation, the team agreed to assess the recently introduced 'Soundserver' product. It was compared to the Apple iPod, which although selling to a different market, was built around similar core technology. Participants completed the audit worksheets, scoring both the Sound-server and the iPod for each issue. The team's discussion addressed product design issues as well as the usability and content of the audit tool itself.

The audit helped raise awareness of many design issues, several of which the company had not previously considered. Specifically, the audit encouraged participants to question the level of functionality offered in the Sound-Server product; wondering if it actually provided too much capability to consumers. The use of a comparative product (iPod) encouraged some divergent thinking, provided some interesting design ideas, challenged their current approach and improved their objectiveness when scoring their own product. They believed their products were visually differentiated, whilst recognising that their brand image was beginning to look old. Furthermore, 
they had not previously considered whether the product's appearance was suitably matched to the tastes of their consumers. The team found the results to be genuinely insightful, providing several new product ideas which they had not previously considered.

Issues such as reliability and durability were currently unknown, although the team made judgements based on visual and tactile impressions. Thus, their scores only captured perceptions towards the product and confirmed the limitations of the audit as a benchmarking tool. Improvement opportunities were captured by adding arrows to the checklists where appropriate (figure 4).

\section{FIGURE 4 ABOUT HERE}

Participant feedback was extremely positive, with only minor changes suggested to improve the audit tool clarity. One participant commented that "(the audit) would allow us to get under the skin of the project ... and whether we have got it right". They commented that the worksheets provided a good way to understand customer requirements, market needs and how the product design might be affected. The audit reminded them of the multitude of issues which need addressing when designing a new product and highlighted the need to be "more thorough" during requirements capture to make sure all issues are considered. The audit encouraged a more customer-focused approach, as the team had to put themselves in the position of a consumer in order to score objectively. Indeed, one participant commented that it had "reminded them that they should be asking (these) key questions and (the product audit) would be a useful way of gaining customer feedback." Despite their combined experience in the development of consumer products, several of the issues were new to the team. In terms of detail and content, they did not disagree with any of the elements and could only identify a few errors of omission or commission.

\section{Case P: Agricultural Machinery}

Company $\mathrm{P}$ has existed for over 30 years, and has an annual turnover of around $f 9 \mathrm{~m}$, employing approximately 130 staff. Roughly ten percent of the workforce was involved in the generation of new products and customising standard products to meet specific customer needs. The company had been owned and managed by the founding family throughout the 30 years. They initially developed novel machinery for farmers and has gradually expanded the product range, to include systems for sorting, cleaning and packing root crops. In this specialised market, the company competes by offering leading technical features and delivering reliable machinery at a competitive price. In addition, they provided customers with a full after-sales offering.

Although technically leading, sales were beginning to be influenced by new market entrants, and as a result had falling gross margins. With increasing competitive pressures, the newly appointed engineering director saw the design audit as a route towards improving product competitiveness. 
Following an initial meeting with senior management to clarify objectives, the product audit was applied over a half day, with a further half-day spent capturing opportunities and actions for improvement. During the workshop, 10 members of staff representing all facets of the business assessed a current product (a 'Crop-washer') to establish strengths and weaknesses, potential improvements and key differentiators. Product producibility was identified as a high priority for improvement. They judged the engineering quality of the products to be high, but also recognised the opportunity to improve both usability and desirability. Participants captured design strengths and weaknesses (figure 5) and identified a number of tangible opportunities for improving the crop-washer. These were later implemented, addressing aspects of benefit to both the company and their customers. Outputs from the product audit also informed a revision of their design process.

\section{FIGURE 5 ABOUT HERE}

Feedback was extremely positive, with the audit tool being judged to be useful, usable and feasible. Several of the worksheets contained content that was new to the group, and the general approach to presenting this material was viewed as original. One participant commented that "the product audit was a completely new challenge to us ... and gave us huge scope with our other products". These observations were supported by questionnaire feedback, with high scores for the clarity and content of the worksheets. Participants believed the audit had helped raise awareness of good design issues and encouraged tangible actions. The management team felt their objectives had been met "to a higher degree than expected" and were delighted with the outputs of the workshop series. Further training in design for manufacture for low volume manufacture was requested.

\section{DISCUSSION}

Companies must continually introduce new products to market, to remain profitable in the face of competitive activity and technological change. Effective products should improve the satisfaction of consumers and users, whilst also resulting in improved business performance. There is both anecdotal and empirical evidence of the value of good design. However, many small companies face specific challenges in the design of new products, often resulting in technically adept products which are either difficult to use or are not desirable to the target audience. Conversely, an attractive product may be let down by poor design for manufacture or weak technical performance. These product deficiencies are indicative of a lack of awareness of the importance of good design and the limited adoption of good design practices.

Through a process of application, review and modification, a robust model of 'good design' in the form of a product audit tool has been developed. The audit tool draws on a wide array of sources, including product aesthetics, design for manufacture, and ergonomics and has proven successful 
in encouraging a more user centred view of product design. Before using the product audit, good design is often viewed parochially in terms of profitability or producibility. By taking a more structured view, with an emphasis on customer perceptions, greater emphasis is given to the softer elements of the design mix, such as aesthetics and ergonomics. Experience from application also suggests that the product audit is an effective way to introduce the company to other design related tool and principles. Company $\mathrm{P}$ for example were later introduced to value analysis and design for assembly techniques. Similarly, the tool encourages a customer/user focused approach to design. The worksheets also potentially provide a mechanism for gathering customer perceptions towards existing products (or proposed designs) in a structured way. In this sense, the tool supports existing approaches such as conjoint analysis or user observation.

A key strength of the final audit tool is its comprehensiveness, covering a wide range of design issues. It does not seek to cover these individual issues with great depth $-\mathrm{a}$ whole research programme for example could have addressed the generation of just a product usability audit. The goal was to produce a usable tool, which meant that a number of difficult judgements had to be made about which activities should be included and which omitted. Whilst it would be possible to criticise the tool for errors of omission, the depth and content of the final audit tool are consistent with the aims of the research; to capture good practice issues in a form accessible to industrialists.

It is important to acknowledge the role of the delivery process on the effectiveness of the audit tool. Clearly the skills and knowledge of the facilitator can have a substantial impact on an engagement. Furthermore, the nature of applied research demands a careful trade-off between the ideal control of variables and the pragmatic need to adapt to the demands of the case companies. These limitations are characteristic of action research approaches and efforts were made to mitigate any potential sources of error, including the triangulation of verbal and written feedback from participants with observations from the facilitator and an independent researcher-observer.

A major challenge in developing a generic audit tool is the reality that a 'one size fits all' solution fundamentally ignores the idiosyncrasies of real companies. It is not anticipated that all companies score highly for all issues or that products should excel across all attributes. The company is given the opportunity to prioritise and assess the importance of each element. However, further work could explore the use of the audit tool across different sectors.

Even though NPD has been studied for almost half a century, many of the lessons are only gradually being adopted in practice [92], especially in SMEs [100]. In 1992, Barclay [101] surveyed around 149 companies and concluded that only 7\% of managers were familiar with the results from the major academic studies. Even when managers are aware, changing product development practices can be difficult when inhibited by ingrained stereotypical behaviour [102]. The outputs of many NPD success factor studies seem to suggest that a structured management process is the key route to success. The need for that process to deliver exceptional products is often 
overlooked. Several studies identify 'product superiority' [e.g. 13, 103] as a key factor, which is in many ways somewhat tautological. To be truly useful to practitioners, some sense of how this superiority is to be achieved is essential. Furthermore, there is an opportunity for success in new product development to be considered from a product as well as a process perspective.

Success factor studies however are only the tip of the iceberg of the body 'good practice' literature. Much of this literature is functionally biased and is (relatively) inaccessible to practicing industrialists. Thus, the product audit aims to take a small step towards capturing some of these lessons, in an accessible form and provides practitioner benefit, by synthesising findings from a diverse array of sources.

\section{CONCLUSIONS}

A 'product audit' tool has been described which encourages attention to be focused on the achievement of 'well-designed' products. The audit tool aims to capture a balanced consideration of 'good design' issues. By drawing together information from a diverse range of sources, this study hopes to raise practitioner awareness of good design issues and provides a useful and usable tool to support managers in improving both products and the design process that delivers them. In use, the tool enables the design team to consider a wide array of design issues, and focuses attention on the benefits that users may derive and the wider user focused aspects of the product. By focusing on the tangible output of the design process - the product - practitioners are better able to understand the way in which design decisions influence product usability, desirability and producibility. Evidence from cases confirms the value and originality of this tool.

\section{ACKNOWLEDGEMENTS}

This research was supported by the Monument Trust. The author is also grateful to Pete Fraser, Nathan Crilly and Pete Caldwell for their input.

\section{REFERENCES}

[1] Black C D, Baker M J, (1987), Success through design, Design Studies, Vol. 8 No. 4, p207-216

[2] Walsh V, Roy R, Bruce M, Potter S, (1992), Winning by design: technology, product design and international competitiveness, Blackwell Business, Oxford

[3] Hertenstein J H, Platt M B, Brown D R, (2001), Valuing design: enhancing corporate performance through design effectiveness, Design Management Journal, Summer

[4] Moultrie J, Fraser P, Clarkson P J, (2002), The innovation-styling spectrum: a framework for the valuation of industrial design involvement in new product introduction, 9th International Product Development Management Conference, Ecoles de Mines, Sophia Antipolis, 27-28 May 2002

[5] Kotler P, Rath G A, (1984), Design: A powerful but neglected strategic tool, Journal of Business Strategy, Vol. 5 No. 2, p16

[6] Huang X, Soutar G N, Brown A, (2002), New product development processes in small and medium sized enterprises: some Australian evidence, Journal of Small Business Management, Vol. 40 No. 1, pp 27-42

[7] Bruce M, Cooper R, Vazquez D, (1999), Effective design management for small businesses, Design Studies, Vol. 20 No. 3, p297

[8] Gorb P, Dumas A, (1987), Silent design, Design Studies, Vol. 8 No. 3, July, p150-156

[9] Norman D A, (1998), The design of everyday things, MIT Press, USA

[10] Wheelwright S. and Clark K. (1992), Creating Product Plans to Focus Product Development, Harvard Business Review March-April 1992. pp 70-82 
[11] Cooper R G, (1993), Winning at new products: accelerating the process from idea to launch, 2nd edition, Perseus Books

[12] McGrath, Michael E. (ed) (1996) Setting the PACE in Product Development: a guide to product and cycletime excellence. Butterworth-Heinemann

[13] Ernst H, (2002), Success factors of new product development: a review of the empirical literature, International Journal of Management Reviews, Vol. 4 No. 1, pp1-40

[14] Cooper R G, (1984), How new product strategies impact on performance, Journal of Product Innovation Management, Vol. 1 No. 1, p5

[15] Page A L, (1993), Assessing new product development practices and performance: establishing crucial norms, Journal of Product Innovation Management, Vol. 10 No. 4, p273

[16] Utterback J, Allen T, Hollomon J, Sirbu M, (1976), The process of innovation in five industries in Europe and Japan, IEEE Transactions on Engineering Management, Vol. 23 No. 1, p3

[17] Eckert C M, Clarkson P J, Stacey M K, (2003), The spiral of applied design research: a methodological view on integrated design research, International Conference on Engineering Design, Stockholm, 2003

[18] Swann C, (2002), Action research and the practice of design, Design Issues, Vol. 18 No. 2

[19] Blessing L, Chakrabarti A, Wallace K, (1995), A design research methodology, International Conference of Engineering Design, Praha, 22-24 August

[20] Platts, (1993), A process approach to researching manufacturing strategy, International Journal of Operations Management, Vol. 13 No. 8, p4-17

[21] Canez L, (2000), Industrial make or buy decisions: developing a framework and practical process, $\mathrm{PhD}$ Dissertation, University of Cambridge, Department of Engineering

[22] Neely A, (1993) 'Production/operations management: research process and content during the 1980s', International Journal of Operations Management, Vol. 13 No.1, pp5-18

[23] Booz, Allen and Hamilton, (1968), Management of new products, Booz Allen and Hamilton, New York

[24] Balbontin A, Yazdani B, Cooper R, Souder W, (1999), New product development success factors in American and British firms, International Journal of Technology Management, Vol. 17 No. 3, p259

[25] Mishra S, Dongwook K, Dae H L, (1999), Factors affecting new product success: cross country comparisons, Journal of Product Innovation Management, Vol. 13, No. 6, pp530-550

[26] Lorenz C, (1994), Harnessing design as a strategic resource, Long Range Planning, Vol. 27 No. 5, p73-84

[27] Nixon B, (1999), Evaluating design performance, International Journal of Technology Management, Vol. 17 issue 7, p814

[28] Rutter B G, Agne J A W, (1998), A Darwinian theory of good design, Design Management Journal, Autumn

[29] Kotler P, Armstrong G, Saunders J, Wong V, (1996), Principles of marketing: the European edition, Prentice Hall, UK

[30] Pugh S, (1996), Creating innovative products using total design: the living legacy of Stuart Pugh, AddisonWesley Publishing, USA

[31] Walsh V, (1985), The designer as 'gatekeeper' in manufacturing industry, Design Studies, Vol. 6 No. 3, p127

[32] Harkins J, (1994), Is design doing its job, Machine Design, February 7th, p53

[33] Gardiner P, Rothwell R, (1985), Tough customers good designs, Design Studies, Vol. 6 No. 1, p7

[34] Monö, R, (1997), Design for Product Understanding, 1st, Liber, Stockholm

[35] Bloch, P. H. (1995) "Seeking the Ideal Form: Product Design and Consumer Response.” Journal of Marketing 59: 16-29

[36] Babbar S, Behara R, White E, (2002), Mapping product usability, International Journal of Operations and Production Management, Vol. 22 No. 10, pp1071-1089

[37] Gobe M, (1993), The 10 best and 10 worst industrial designs, Industrial Design, June, p22

[38] Flurscheim C H, (1983), Industrial Design in Engineering, The Design Council, London

[39] Bruseberg A, McDonagh-Philip D, (2002), Focus groups to support the industrial/product designer: a review based on current literature and designers' feedback, Applied Ergonomics: Human Factors in Technology and Society, Vol. 31 No. 1 pp 27-38

[40] Porter M E, (1985), Competitive advantage - creating and sustaining superior performance, The Free Press, New York, USA

[41] Trueman M, (1997) 'Demystifying innovation by design', Proc. 7th International Forum on Technology Management, Kyoto, Japan, 3-7 November 1997

[42] Bruce M, (1985), The design process and the 'crisis' in the UK information industry, Design Studies, Vol. 6 No. $1, \mathrm{p} 34$

[43] Tarasewich P, (1996), Design for success, IM, March/April, p28-32

[44] Horenstein M, (1999), Design Concepts for Engineers, Prentice Hall, USA

[45] March A, (1994), Usability: the new dimensions, Harvard Business Review, September-October

[46] Jordan P W, (2000), Designing pleasurable products: an introduction to the new human factors), Taylor \& Francis, London 
[47] Crilly N, Moultrie J, Clarkson P J, (2004), Seeing things: consumer response to the visual domain in product design, Design Studies, Vol. 25 No. 66, pp547-577

[48] Bralla J, (1998), Design for manufacturability handbook 2nd edition, McGraw Hill

[49] Galsworth, (1994), Smart Simple Design - Using Variety Effectiveness To Reduce Total Cost And Maximise Customer Selection, Oliver Wright Publications, USA

[50] Meyer M H, Lehnard A P, (1997), The Power of Product Platforms - Building Value and Cost Leadership, The Free Press, New York

[51] Cagan J, Vogel C M, (2002), Creating breakthrough products: innovation from product planning to program approval, Prentice Hall, Upper Saddle River, New Jersey

[52] Little A D, (1991), The Arthur D Little survey on the product innovation process, Arthur D Little: Cambridge MA

[53] Ulrich K T, Eppinger S D, (2000), Product design and development, McGraw-Hill, USA

[54] Meyer M H, Utterback J M, (1993), The product family and the dynamics of core capability, Sloan Management Review, Vol. 34 No. 3, p29

[55] Dalgleish G F, Jared G E M, Swift K G, (2000), Design for assembly: influencing the design process, Journal of Engineering Design, Vol. 11 No. 1

[56] Hermann J W, Cooper J, Gupta S K, Hayes C C, Ishii K, Kazmer D, Sandborn P A, Wood W H, (2004), New directions in design for manufacturing, Proceedings of DECT'04, ASME 2004 Design and Technical Conferences and Computers and Information in Engineering Conference, Sept 28th to Oct 2nd "004, Salt Lake City, Utah USA

[57] Cutherell D, (1996), Product Architecture, The PDMA Handbook of New Product Development, p217-235

[58] Baldwin C Y, Clark K B, (1997), Managing in an age of modularity, Harvard Business Review, Vol. 75 No. 5, p84-93

[59] Otto K, Wood K, (2001), Product design: techniques in reverse engineering and new product development, Prentice Hall, USA

[60] Nussbaum B, (1988), Smart design, Business Week, April 11

[61] Frijda N H, (1986), The emotions: studies in emotion and social interaction, Cambridge University Press, Cambridge

[62] Desmet P, (2003), A multilayered model of product emotions, The Design Journal, Vol. In Press

[63] Coates D, (2003), Watches tell more than time: product design information and the quest for elegance, McGraw-Hill, London

[64] Dittmar H, (1992), The social psychology of material possessions: to have is to be, St Martin's Press, New York

[65] Pepper S C, Munro T, (1977), Encyclopaedia Britannica / Macropaedia 1, 15th

[66] Crozier W R, (1994), Manufactured pleasures: psychological response to design, Manchester University Press, Manchester

[67] Cupchik G C, (1999), Emotion and industrial design: reconciling meanings and feelings, First International Conference on Design \& Emotion, Delft, The Netherlands, pp 75-82

[68] Baxter M, (1995), Product design: A practical guide to systematic methods of new product development, Chapman \& Hall, London

[69] Veryzer R W J, (1993), Aesthetic response and the influence of design principles on product preferences, Advances in Consumer Research, Vol.20

[70] Routio P, (2002), Beauty of artefacts, Website: http://www2.uiah.fi/projects/metodi/155.htm, Accessed on $26 / 08 / 04$

[71] Arnheim R, (1992), But is it Science?, in Emerging visions of the aesthetic process: psychology, semiology, and philosophy, edited by G. C. Cupchik and J. László, Cambridge University Press, Cambridge

[72] Elam K, (2001), Geometry of design: studies in proportion and composition, Princeton Architectural Press, New York

[73] Itten J, (1997), Design and form: the basic course at the Bauhaus, Revised edition, Thames \& Hudson, London

[74] Lewalski Z M, (1988), Product esthetics: an interpretation for designers, Design \& Development Engineering Press, Carson City, Nevada

[75] Berlyne D E, (1974), Studies in the new experimental aesthetics, Hemisphere Publishing Corporation, Washington

[76] Gombrich E H, (1984), The sense of order: a study in the psychology of decorative art, 2nd, Phaidon, Oxford

[77] Hekkert P, Snelders D, Wieringen P C W, (2003), Most advanced, yet acceptable: typicality and novelty as joint predictors of aesthetic preference in industrial design British Journal of Psychology, Vol.2003, No.94, pp 111-124

[78] Janlert L-E, (1997), The character of things, Design Studies, Vol.18, pp 297-314 
[79] Ornstein R E, (1992), The evolution of consciousness: Of Darwin, Freud and cranial fire: the origins of the way we think, Touchstone, New York

[80] Robert F, Robert J, (2000), Faces, Chronicle Books, USA

[81] Mayall M H, (1979), Principles in design, Design Council, London, UK

[82] Goffman E, (1990), The Presentation of Self in Everyday Life, Penguin

[83] Muller W, (2001), Order and meaning in design, LEMMA Publishers, Utrecht, Holland

[84] Pheasant S, (2001), Bodyspace: anthropometry ergonomics and the design of work, Taylor Francis Limited, London

[85] Roebuck J A, (1995), Anthropometric methods: designing to fit the human body (monographs in human factors and ergonomics), Human Factors \& Ergonomics Society

[86] Hennermann R L, (1999), Design for usability: process skills and tools, Information-Knowledge-Systems Management, Vol. 1 p133

[87] Tilley A R, (2002), The measure of man and woman: human factors in deign, Revised Edition, John Wiley $\&$ Sons, New York

[88] Krippendorff K, (1989), On the essential contexts of artefacts or on the proposition that design is making sense (of things) Design Issues, Vol.5, No.2, pp9-38

[89] Djajadiningrat J P, Gaver W W, Frens J W, (2000), Interaction relabelling and extreme characters: methods for exploring aesthetic interactions. Proceedings of DIS'00, Designing Interactive Systems, ACM, New York

[90] Keates S, Clarkson P J, (2003), Countering design exclusion: an introduction to inclusive design, SpringerVerlag Limited, London

[91] Lilien G, Yoon E, (1989), Determinants of new industrial product performance: a strategic re-examination of the empirical literature, IEE Transactions in Engineering Management, Vol. 36 No. 1, p3

[92] Cooper R G, (1999), "From Experience: The Invisible Success Factors in Product Innovation", Journal of Product Innovation Management, 16: 115-133

[93] Lazo H, (1965), Finding a key to success in new product failures, Industrial Marketing, No 50, Nov, p74

[94] Park K S, Lim C H, (1999), A structured methodology for comparative evaluation of user interface designs using usability criteria and measures, International Journal of Industrial Ergonomics, Vol. 23 pp379-389

[95] Bevan N, Kirakowski J, Maissel J, (1991), What is usability?, Proceedings of the 4th International Conference on Human Computer Interaction, September 1991

[96] Han S H, Yun M H, Kim K-J, Kwahk J, (2000), Evaluation of product usability: development and validation of usability dimensions and design elements based on empirical models, International Journal of Industrial Ergonomics, Vol. 26, p477

[97] Nielsen J, (1993), Usability engineering, A P Professional, NY

[98] Hsu S H, Chuang M C, Chang C C A, (2000), Semantic differential study of designers' and users' product form perception International Journal of Industrial Ergonomics, Vol.25, pp 375-391

[99] Osgood C E, (1976), Focus on Meaning, Moulton \& co., B V Publishers, The Hague

[100] Brown K, Schmied H, Tarondeau J-C, (2003), Success factors in R\&D: a meta analysis of the empirical literature and derived implications for design management, Design Management Journal, Academic Review, Vol. 2

[101] Barclay I, (1992), The new product development process: past evidence and future practical application part 1, R\&D Management, Vol. 22 No. 3, p255

[102] Karlsson C, Ahlstrom P, (1996), The Difficult Path to Lean Product Development, Journal of Product Innovation Management, 13: 283-295

[103] Montoya-Weiss M, Calantone R, (1994), Determinants of new product performance, Journal of Product Innovation Management, Vol. 11, p397 
FIGURES \& TABLES

\begin{tabular}{|c|c|c|c|c|}
\hline & Case company & Sector / Products & $\mathrm{T} / 0 \mathrm{£m}$ & Staff \\
\hline \multirow{4}{*}{ 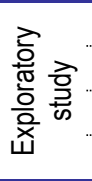 } & $A$ & Optical medical products & $£ 12.0 \mathrm{~m}$ & 133 \\
\hline & $B$ & Paper handling and collation & $£ 4.0 \mathrm{~m}$ & 80 \\
\hline & $\mathrm{C}$ & Medical emergency products & $£ 5.5 \mathrm{~m}$ & 100 \\
\hline & D & Industrial radios & NA & NA \\
\hline \multirow{9}{*}{ 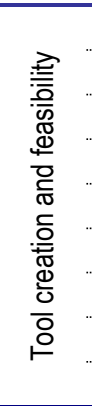 } & $E$ & Scientific instruments & $£ 1.2 \mathrm{~m}$ & 25 \\
\hline & $\mathrm{F}$ & Industrial ink-jet printing & $£ 150 \mathrm{~m}$ & 1500 \\
\hline & G & Software & $£ 3.0 \mathrm{~m}$ & 45 \\
\hline & $\mathrm{H}$ & Design consultancy & $£ 1.0 \mathrm{~m}$ & 12 \\
\hline & 1 & Food machinery & $£ 20.0 \mathrm{~m}$ & 200 \\
\hline & $J$ & Consumer tools & NA & NA \\
\hline & $\mathrm{K}$ & Consumer $\mathrm{Hi}-\mathrm{Fi}$ & $£ 10.0 \mathrm{~m}$ & 110 \\
\hline & L & Building supplies & $£ 15.0 \mathrm{~m}$ & 250 \\
\hline & M & Security electronics & $£ 3.0 \mathrm{M}$ & 50 \\
\hline \multirow{3}{*}{ 응 } & $\mathrm{N}$ & Medical lasers & $£ 6.0 \mathrm{~m}$ & 70 \\
\hline & 0 & Specialist Hi-Fi & $£ 3.5 \mathrm{~m}$ & 30 \\
\hline & $P$ & Agricultural machinery & $£ 9.0 \mathrm{~m}$ & 130 \\
\hline \multirow{10}{*}{ 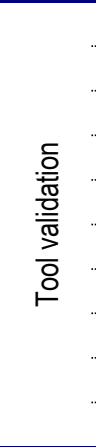 } & $Q$ & Instrumentation: Spectrometers & $£ 10 \mathrm{~m}$ & 75 \\
\hline & $\mathrm{R}$ & Instrumentation: Sensors & $£ 540 \mathrm{~m}$ (Group) & 660 (Group) \\
\hline & $S$ & Instrumentation: Scientific equipment & $£ 6 m$ & 100 \\
\hline & $\mathrm{T}$ & Instrumentation: Hygrometers & $£ 5 m$ & 60 \\
\hline & U & Instrumentation: Sensing \& control & Group $£ 23 b n$ & Group 15,000 \\
\hline & V & Consumer electronics: Audio & $£ 3.5 \mathrm{~m}$ & 30 \\
\hline & W & Consumer goods: White goods & $>£ 20 \mathrm{~m}$ & $>200$ \\
\hline & $x$ & Industrial goods: Building supplies & $£ 15 m$ & 275 \\
\hline & Y & Consumer electronics: Audio & $£ 4 m$ & 45 \\
\hline & Z & Design consultancy & $£ 0.75 \mathrm{~m}$ & 12 \\
\hline
\end{tabular}

Table 1: Summary of cases 


\begin{tabular}{|c|c|c|c|c|}
\hline & Description & Product attribute & Design Awards & References \\
\hline \multirow[b]{2}{*}{$\begin{array}{c}\text { Core } \\
\text { product }\end{array}$} & \multirow{2}{*}{$\begin{array}{l}\text { The underlying need for the } \\
\text { product, its degree of } \\
\text { functionality, the availability } \\
\text { of alternative solutions and } \\
\text { its perceived value in the } \\
\text { market place }\end{array}$} & $\begin{array}{l}\text { Utility \& functionality, fit for } \\
\text { purpose }\end{array}$ & $\begin{array}{l}1,2,3,4,5,7,8 \\
9,10,11,12\end{array}$ & $\begin{array}{l}28,32,35,36 \\
37\end{array}$ \\
\hline & & $\begin{array}{l}\text { Need / appropriate benefits / } \\
\text { concept or idea }\end{array}$ & $5,6,7,14$ & $35,39,40,51$ \\
\hline \multirow{5}{*}{$\begin{array}{c}\text { Actual } \\
\text { product }\end{array}$} & \multirow{5}{*}{$\begin{array}{l}\text { Tangible and intangible } \\
\text { physical attributes that } \\
\text { represent the embodiment } \\
\text { of the core product benefits } \\
\text { in real components and } \\
\text { technology. }\end{array}$} & $\begin{array}{l}\text { Desirability: aesthetics, } \\
\text { appearance, style, emotional } \\
\text { appeal, image, finish }\end{array}$ & $\begin{array}{l}1,3,4,6,7,9 \\
10,11,12,13 \\
14,15\end{array}$ & $\begin{array}{l}27,28,31,35 \\
37,39,41,42, \\
47\end{array}$ \\
\hline & & $\begin{array}{l}\text { Usability: Ergonomics \& safety } \\
\text { (physical \& cognitive) }\end{array}$ & $\begin{array}{l}1,2,4,5,7,8,9 \\
10,11,12,13,14\end{array}$ & $\begin{array}{l}28,31,36,42 \\
43,45,46\end{array}$ \\
\hline & & $\begin{array}{l}\text { Technical quality: reliability, } \\
\text { durability, technical performance }\end{array}$ & $\begin{array}{l}4,5,6,9,10,11 \\
14\end{array}$ & $\begin{array}{l}3,2,5,28,31 \\
44\end{array}$ \\
\hline & & $\begin{array}{l}\text { Design for X: production, cost, } \\
\text { service }\end{array}$ & $1,5,12$ & $\begin{array}{l}41,43,44,48 \\
49,50\end{array}$ \\
\hline & & Innovativeness / novelty & $\begin{array}{l}1,3,4,5,7,8,9 \\
11,12,15\end{array}$ & $16,25,28,35$ \\
\hline \multirow{3}{*}{$\begin{array}{l}\text { Augmented } \\
\text { product }\end{array}$} & \multirow{3}{*}{$\begin{array}{l}\text { Product related services that } \\
\text { are a central aspect of the } \\
\text { product offering to } \\
\text { customers }\end{array}$} & Availability / Delivery & $\begin{array}{l}1,3,4,5,7,8,9 \\
10,11,12,15\end{array}$ & $31,39,40$ \\
\hline & & Promotion \& marketability & $1,6,9,11,12$ & 31,43 \\
\hline & & Ethical / environmental issues & $\begin{array}{l}1,3,4,5,7,8,9 \\
10,11,12,15\end{array}$ & - NA - \\
\hline $\begin{array}{c}\text { Meta } \\
\text { product }\end{array}$ & $\begin{array}{l}\text { The underlying business } \\
\text { model of the product, and } \\
\text { the wider range of business } \\
\text { processes/activities needed } \\
\text { to support it }\end{array}$ & $\begin{array}{l}\text { Business model: sales price / } \\
\text { value / life costs / trade in value } \\
\text { / depreciation }\end{array}$ & $1,2,6,12$ & $31,40,41,43$ \\
\hline
\end{tabular}

\section{Design awards}

1 Australian design awards, 2 Canadian National Post design exchange awards, 3 Danish design prize, 4 German Red dot, 5 German IF design award, 6 Italian Golden Compass, 7 Japan G Mark, 8 Korean good industrial design awards, 9 Norway award for excellence, 10 Taiwan Good Design Product Selection, 11 Singapore design award, 12 Spanish national design prize, 13 Swedish excellent design prize, 14 UK Design \& Art Direction awards, 15 USA Industrial Design Excellence Awards

Table 2: Good design - product attributes from literature \& design awards 


\begin{tabular}{|c|c|}
\hline \multicolumn{2}{|c|}{ Does the arrangement \& layout of interface elements follow ergonomics guidelines? } \\
\hline Yes & No \\
\hline
\end{tabular}

Scale \#1 - binary yes/no scale

\begin{tabular}{|cccccc|}
\hline \multicolumn{4}{|c|}{ The arrangement \& layout of interface elements follows ergonomics guidelines, is a good arrangement and is easy to understand. } \\
\hline 1 & 2 & 3 & 5 & 6 & 7 \\
Strongly disagree & Disagree & Agree & Strongly agree \\
\hline
\end{tabular}

Scale \#2 - Likert style scale

\begin{tabular}{|c|c|c|c|c|c|c|}
\hline \multicolumn{7}{|c|}{ Does the arrangement \& layout of interface elements follow ergonomics guidelines? } \\
\hline 1 & 2 & 3 & 4 & 5 & 6 & 7 \\
\hline $\begin{array}{l}\text { Very poor } \\
\text { arrangement and } \\
\text { layout. Very } \\
\text { confusing }\end{array}$ & & $\begin{array}{c}\text { Poor } \\
\text { arrangement \& } \\
\text { layout. Confusing }\end{array}$ & & $\begin{array}{l}\text { Fair arrangement } \\
\text { \& layout. Easy to } \\
\text { understand }\end{array}$ & & $\begin{array}{l}\text { Very good } \\
\text { arrangement \& } \\
\text { layout. Very easy } \\
\text { to understand }\end{array}$ \\
\hline
\end{tabular}

Scale \#3- modified Likert style scale [Han 2000]

\begin{tabular}{|cccc|}
\hline \multicolumn{4}{|c|}{ Does the arrangement \& layout of interface elements follow ergonomics guidelines? } \\
\hline $\begin{array}{c}\text { Very poor arrangement and } \\
\text { layout. Very confusing }\end{array}$ & $\begin{array}{c}\text { Poor arrangement \& layout. } \\
\text { Confusing }\end{array}$ & $\begin{array}{c}\text { Fair arrangement \& layout. Easy } \\
\text { to understand }\end{array}$ & $\begin{array}{c}\text { Very good arrangement \& } \\
\text { layout. Very easy to understand }\end{array}$ \\
\hline
\end{tabular}

Scale \#4 - 'maturity' scale with multiple anchor phrases

Does the arrangement \& layout of interface elements follow ergonomics guidelines?
Arrangement and layout of interface

elements on the body is poor and confusing

$\begin{array}{cccc}1 & 3 & 4 & 4\end{array}$

Scale \#5 - scale with anchor phrases at each end

Figure 1: Product audit scale design

Arrangement and layout of interface
elements on the body is very good and
very easy to understand
very easy to understand 
Meta product: Brand, Business model, Strategy, Production system

Augmented Product: Service \& support, Finance and warranty, Delivery, Installation

Core Product: Tangible and intangible product attributes

Usability

$>$ Getting started

$>$ Interface clarity

$>$ Physical usability

Core benefits

$>$ Need

$>$ Functionality

$>$ Alternatives

$>$ Value
> Maintenance \& cleaning

Engineering Quality

$>$ Performance

$>$ Reliability

$>$ Build quality

> Durability
Desirability

$>$ Aesthetics

$>$ Symbolism \& status

$>$ Visual clarity

$>$ All senses

$>$ Pride

$>$ Emotional response

Producibility

$>$ Component manufacture

$>$ Assembly \& test

> Platform strategy
Novelty \&

Differentiation

$>$ Core benefits

$>$ Functions \& features

> Technology

> Technical quality

$>$ Aesthetics

$>$ Usability

$>$ Brand

$>$ After-sales support

$>$ Finance \& warranty

$>$ Delivery

$>$ Others

FIGURE 2: architecture of the product audit

\begin{tabular}{|c|c|c|c|c|c|c|}
\hline \multirow[t]{2}{*}{ Issue } & \multirow{2}{*}{$\begin{array}{r}\text { Poor performance } \\
\text { No visual novelty }- \text { it looks like all the rest }\end{array}$} & \multicolumn{4}{|c|}{ Score (1-4) } & \multirow{2}{*}{$\begin{array}{l}\text { Great performance } \\
\text { Novel aesthetics give it a strong identity - visually } \\
\text { differentiated from competition }\end{array}$} \\
\hline & & 1 & 2 & 3 & 4 & \\
\hline \multirow{3}{*}{ Aesthetics } & $\begin{array}{r}\text { No/too much 'contrast' between elements - tone, } \\
\text { shape, colour, line }\end{array}$ & 1 & 2 & 3 & 4 & $\begin{array}{l}\text { Just the right amount of 'contrast' between elements - } \\
\text { tone, shape, colour, line }\end{array}$ \\
\hline & $\begin{array}{r}\text { No sense of 'order' to the design - an incoherent and } \\
\text { inharmonious collection of elements }\end{array}$ & 1 & 2 & 3 & 4 & $\begin{array}{l}\text { A high sense of 'order' to the design - a pleasing } \\
\text { harmony of shapes, material, finish, colour and structure }\end{array}$ \\
\hline & $\begin{array}{r}\text { Its appearance is inappropriate and does not make } \\
\text { sense - it just looks wrong! }\end{array}$ & 1 & 2 & 3 & 4 & Its appearance makes complete sense - it just looks right! \\
\hline \multirow{3}{*}{$\begin{array}{l}\text { Symbolism } \\
\text { and status }\end{array}$} & $\begin{array}{r}\text { Ownership has no (or a detrimental) impact on 'status' } \\
\text { amongst the peer group of target market }\end{array}$ & 1 & 2 & 3 & 4 & $\begin{array}{l}\text { Ownership improves 'status' amongst the peer group of } \\
\text { target market }\end{array}$ \\
\hline & $\begin{array}{r}\text { It does not represent or express the tastes or values } \\
\text { of its target market }\end{array}$ & 1 & 2 & 3 & 4 & $\begin{array}{l}\text { It accurately symbolises or expresses the values, beliefs } \\
\text { and tastes of its target audience }\end{array}$ \\
\hline & $\begin{array}{r}\text { Appearance is inappropriate for the context or } \\
\text { environment of use }\end{array}$ & 1 & 2 & 3 & 4 & $\begin{array}{l}\text { Appearance is appropriate for the intended context or } \\
\text { environment of use }\end{array}$ \\
\hline \multirow{3}{*}{$\begin{array}{l}\text { Visual } \\
\text { clarity }\end{array}$} & $\begin{array}{r}\text { No clear brand identity or coherence across the full } \\
\text { product range }\end{array}$ & 1 & 2 & 3 & 4 & $\begin{array}{l}\text { Design reinforces and reflects the company's brand values } \\
\text { and identity }\end{array}$ \\
\hline & $\begin{array}{r}\text { Appearance is inconsistent with expected values - e.g. } \\
\text { tough, precious, fun etc }\end{array}$ & 1 & 2 & 3 & 4 & $\begin{array}{l}\text { Design expresses and reinforces specific qualities and } \\
\text { values - e.g. fast, accurate, tough etc. }\end{array}$ \\
\hline & $\begin{array}{l}\text { Confusing appearance which gives few clues to } \\
\text { describe the purpose and use of the product }\end{array}$ & 1 & 2 & 3 & 4 & $\begin{array}{l}\text { Appearance helps to clearly describe the product } \\
\text { purpose, function and operation }\end{array}$ \\
\hline All senses & $\begin{array}{r}\text { Feels, smells or sounds horrible - little sensory } \\
\text { pleasure (touch, feel etc) }\end{array}$ & 1 & 2 & 3 & 4 & $\begin{array}{l}\text { Feels as good as it looks: Sensual pleasure through } \\
\text { comfort, material or texture }\end{array}$ \\
\hline Pride & $\begin{array}{r}\text { Little pride of ownership, design is utilitarian and } \\
\text { functional - it gets hidden away }\end{array}$ & 1 & 2 & 3 & 4 & $\begin{array}{l}\text { Design inspires a sense of pride in buying and owning - it } \\
\text { may even go on display }\end{array}$ \\
\hline \multirow[t]{2}{*}{$\begin{array}{l}\text { Emotional } \\
\text { response }\end{array}$} & $\begin{array}{l}\text { Product produces a negative emotional response - it } \\
\text { makes me feel cross, frustrated, angry, upset etc. }\end{array}$ & 1 & 2 & 3 & 4 & $\begin{array}{l}\text { Product produces a positive emotional response - it } \\
\text { makes me feel happy, satisfied, reassured etc. }\end{array}$ \\
\hline & Overall low desirability & 1 & 2 & 3 & 4 & Overall high desirability \\
\hline
\end{tabular}

FIGURE 3: example product audit worksheet - product desirability 


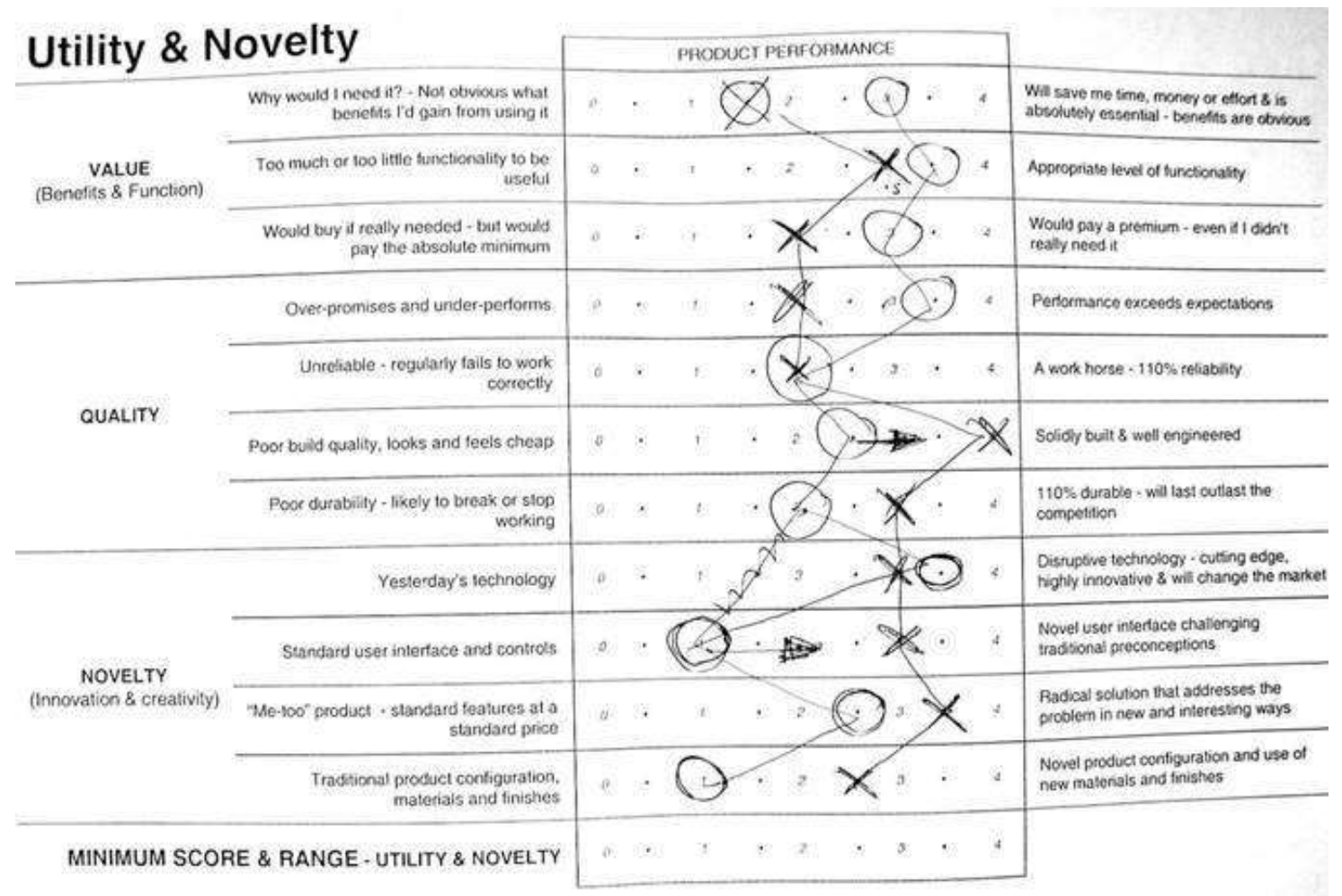

FIGURE 4: Example worksheet from Company $O$ 


\begin{tabular}{|c|c|c|}
\hline & Weaknesses & Strengths \\
\hline Core benefits & $\begin{array}{l}\text { - Too expensive to buy } \\
\text { - High competition } \\
\text { - Excessive functionality }\end{array}$ & $\begin{array}{l}\text { - High throughput } \\
\text { - Long life } \\
\text { - Good functionality (fit for purpose) }\end{array}$ \\
\hline $\begin{array}{l}\text { Engineering } \\
\text { quality }\end{array}$ & $\begin{array}{l}\text { - Over engineered (parts) } \\
\text { - Only performs to spec }\end{array}$ & $\begin{array}{l}\text { - Very reliable } \\
\text { - Well built } \\
\text { - Good performer }\end{array}$ \\
\hline Usability & $\begin{array}{l}\text { - Hard to clean, lacking documents } \\
\text { - Poor maintainability (no manuals) } \\
\text { - Too many fasteners }\end{array}$ & $\begin{array}{l}\text { - Simple to use, good interface } \\
\text { - Relatively sage, flexible } \\
\text { - Robust, won't self destruct! }\end{array}$ \\
\hline Desirability & $\begin{array}{l}\text { - No sense of order to the design } \\
\text { - Confusing appearance } \\
\text { - Ugly }\end{array}$ & $\begin{array}{l}\text { - Strong brand name, identifiable } \\
\text { - Pride in ownership, status symbol }\end{array}$ \\
\hline Producibility & $\begin{array}{l}\text { - Large components, specialist tools } \\
\text { - Too many parts } \\
\text { - Critical components, therefore waste } \\
\text { - Upgrades organic \& unstructured }\end{array}$ & $\begin{array}{l}\text { - Ease of assembly - minimal tooling } \\
\text { - Simple controls, minimal hydraulics \& electrics }\end{array}$ \\
\hline Profitability & $\begin{array}{l}\text { - Good but reducing market share } \\
\text { - Low volume / low profit }\end{array}$ & $\begin{array}{l}\text { - Good profit } \\
\text { - Low warranty \& support costs }\end{array}$ \\
\hline $\begin{array}{l}\text { Novelty / } \\
\text { differentiation }\end{array}$ & $\begin{array}{l}\text { - Yesterdays technology (though established) } \\
\text { - Visually poor }\end{array}$ & $\begin{array}{l}\text { - Good delivery } \\
\text { - Unique features (door, brush, bolt-ons) } \\
\text { - Brand name components }\end{array}$ \\
\hline
\end{tabular}

Figure 5: Summary of product strengths and weaknesses 


\section{APPENDIX 1: THE COMPLETE PRODUCT AUDIT}

Core benefits ...

\begin{tabular}{|c|c|c|c|c|c|c|}
\hline \multirow{2}{*}{$\begin{array}{l}\text { Issue } \\
\text { Need }\end{array}$} & \multirow{2}{*}{$\begin{array}{r}\text { Poor performance } \\
\begin{array}{r}\text { Why would I need it? - Not obvious what benefits the } \\
\text { target audience would gain from using it }\end{array}\end{array}$} & \multicolumn{4}{|c|}{ Score (1-4) } & \multirow{2}{*}{$\begin{array}{l}\text { Great performance } \\
\text { Will save its target market time, money or effort \& is } \\
\text { absolutely essential - benefits are obvious }\end{array}$} \\
\hline & & 1 & 2 & 3 & 4 & \\
\hline Functionality & Too much or too little functionality to be really useful & 1 & 2 & 3 & 4 & Appropriate level of functionality - and no more \\
\hline Alternatives & $\begin{array}{r}\text { Lots of alternatives out there perform the same function } \\
- \text { often better }\end{array}$ & 1 & 2 & 3 & 4 & $\begin{array}{l}\text { There are no viable alternatives to this product - which } \\
\text { have the same capabilities }\end{array}$ \\
\hline \multirow[t]{2}{*}{ Value } & $\begin{array}{r}\text { Would buy if it was really needed - but would pay the } \\
\text { absolute minimum }\end{array}$ & 1 & 2 & 3 & 4 & Would pay a premium - even if it wasn't really needed \\
\hline & Overall few real benefits & 1 & 2 & 3 & 4 & Overall significant benefits \\
\hline
\end{tabular}

Engineering quality ...

\begin{tabular}{|rr|c|c|c|c|c}
\multicolumn{1}{c|}{ Issue } & Poor performance & & Score & (1-4) & Great performance \\
\hline Performance & Over promises and under performs & 1 & 2 & 3 & 4 & Performance exceeds expectations \\
\hline Reliability & Pnreliable - regularly fails to work correctly & 1 & 2 & 3 & 4 & A work horse - 100\% reliability \\
\hline Build quality & Poor build quality - looks and feels cheap & 1 & 2 & 3 & 4 & Solidly built and well engineered \\
\hline Durability & Poor durability - likely to break or stop working & 1 & 2 & 3 & 4 & $110 \%$ durability - will outlast the competition \\
\hline Overall poor engineering quality & 1 & 2 & 3 & 4 & Overall great engineering quality
\end{tabular}

\section{Profitability ...}

\begin{tabular}{|c|c|c|c|c|c|c|}
\hline \multirow{2}{*}{$\begin{array}{l}\text { Issue } \\
\text { Income }\end{array}$} & \multirow{2}{*}{$\begin{array}{l}\text { Poor performance } \\
\text { Lower income than planned }\end{array}$} & \multicolumn{4}{|c|}{ Score (1-4) } & \multirow{2}{*}{$\begin{array}{l}\text { Great performance } \\
\text { Income exceeds expectations }\end{array}$} \\
\hline & & 1 & 2 & 3 & 4 & \\
\hline $\begin{array}{l}\text { Production } \\
\text { costs }\end{array}$ & Unit cost too high & 1 & 2 & 3 & 4 & Unit cost lower than expected \\
\hline $\begin{array}{c}\text { Selling \& } \\
\text { support costs }\end{array}$ & Costs too much to sell and support & 1 & 2 & 3 & 4 & Selling and support costs lower than expected \\
\hline $\begin{array}{l}\text { Profit (per } \\
\text { unit) }\end{array}$ & Margins are too low & 1 & 2 & 3 & 4 & Margins exceed expectations \\
\hline \multirow[t]{2}{*}{ Market share } & Small share of a shrinking market & 1 & 2 & 3 & 4 & Good share of a growing market \\
\hline & Overall poor profitability & 1 & 2 & 3 & 4 & Overall good profitability \\
\hline
\end{tabular}




\begin{tabular}{|c|c|c|c|c|c|c|}
\hline \multirow[t]{2}{*}{ Issue } & \multirow{2}{*}{$\begin{array}{r}\text { Poor performance } \\
\begin{array}{r}\text { Poor packaging - difficult to get into, waste of materials, } \\
\text { and unclear instructions / graphics }\end{array}\end{array}$} & \multicolumn{4}{|c|}{ Score (1-4) } & \multirow{2}{*}{$\begin{array}{l}\text { Great performance } \\
\begin{array}{l}\text { Great packaging - easy to access, beautifully designed, } \\
\text { unambiguous and obvious how to access }\end{array} \\
\end{array}$} \\
\hline & & 1 & 2 & 3 & 4 & \\
\hline \multirow[t]{5}{*}{$\begin{array}{l}\text { Getting } \\
\text { started }\end{array}$} & Needs several weeks of training just to get started & 1 & 2 & 3 & 4 & Training either not needed or well provided \\
\hline & Handbook, manual or documentation next to useless & 1 & 2 & 3 & 4 & Supporting documentation is clear, concise and useful \\
\hline & User interface ignores accepted rules and conventions & 1 & 2 & 3 & 4 & $\begin{array}{l}\text { Interface follows (or improves) accepted rules \& } \\
\text { conventions - it is compatible with similar devices }\end{array}$ \\
\hline & Little layering of information or prioritisation of functions & 1 & 2 & 3 & 4 & $\begin{array}{l}\text { The most important information/functions are the most } \\
\text { accessible and are clearly prioritised }\end{array}$ \\
\hline & Frequent \& unrecoverable errors & 1 & 2 & 3 & 4 & $\begin{array}{l}\text { Little likelihood of errors - but when they happen, recovery } \\
\text { is simple }\end{array}$ \\
\hline \multirow[t]{4}{*}{$\begin{array}{l}\text { Interface } \\
\text { clarity }\end{array}$} & Little or no feedback between action and effect & 1 & 2 & 3 & 4 & $\begin{array}{l}\text { Clear \& obvious feedback lets you know when actions are } \\
\text { performed }\end{array}$ \\
\hline & $\begin{array}{r}\text { Little or no natural mapping between controls and } \\
\text { resulting actions }\end{array}$ & 1 & 2 & 3 & 4 & $\begin{array}{l}\text { Clear \& obvious natural mapping between controls \& } \\
\text { resulting actions }\end{array}$ \\
\hline & $\begin{array}{r}\text { Few designed in-constraints to prevent errors or guide } \\
\text { actions }\end{array}$ & 1 & 2 & 3 & 4 & $\begin{array}{l}\text { Appropriate constraints designed in to prevent errors and } \\
\text { guide actions }\end{array}$ \\
\hline & $\begin{array}{r}\text { Interface is unlikely to be understood by much of the } \\
\text { target population }\end{array}$ & 1 & 2 & 3 & 4 & $\begin{array}{l}\text { Interface will be understood by both the target and the } \\
\text { wider population }\end{array}$ \\
\hline \multirow{2}{*}{$\begin{array}{l}\text { Physical } \\
\text { usability }\end{array}$} & $\begin{array}{r}\text { Physical elements have the wrong size, shape and } \\
\text { arrangement to be used comfortably }\end{array}$ & 1 & 2 & 3 & 4 & $\begin{array}{l}\text { All elements have the right size, shape and arrangement } \\
\text { for users in the target population }\end{array}$ \\
\hline & $\begin{array}{r}\text { Size, shape or position of elements cannot be adjusted } \\
\text { to suit the needs of different users }\end{array}$ & 1 & 2 & 3 & 4 & All necessary adjustments well catered for \\
\hline \multirow{2}{*}{$\begin{array}{l}\text { Maintenance } \\
\& \text { Cleaning }\end{array}$} & $\begin{array}{r}\text { Difficult to service, maintain \& repair - specialist input is } \\
\text { expensive / unavailable }\end{array}$ & 1 & 2 & 3 & 4 & $\begin{array}{l}\text { Service, maintenance \& repair either simple or not needed } \\
\text { - specialist input is readily available }\end{array}$ \\
\hline & $\begin{array}{r}\text { Difficult-to clean - nooks, crannies and hard-to-access } \\
\text { areas or easily damaged materials }\end{array}$ & 1 & 2 & 3 & 4 & $\begin{array}{l}\text { Easy to clean - appropriate materials, easy access, smooth } \\
\text { surfaces, clear visibility }\end{array}$ \\
\hline
\end{tabular}

\section{Desirability ...}

\begin{tabular}{|c|c|c|c|c|c|c|}
\hline Issue & Poor performance & \multicolumn{4}{|c|}{ Score (1-4) } & Great performance \\
\hline \multirow{4}{*}{ Aesthetics } & No visual novelty - it looks like all the rest & 1 & 2 & 3 & 4 & $\begin{array}{l}\text { Novel aesthetics give it a strong identity - visually } \\
\text { differentiated from competition }\end{array}$ \\
\hline & $\begin{array}{r}\text { No/too much 'contrast' between elements - tone, } \\
\text { shape, colour, line }\end{array}$ & 1 & 2 & 3 & 4 & $\begin{array}{l}\text { Just the right amount of 'contrast' between elements - } \\
\text { tone, shape, colour, line }\end{array}$ \\
\hline & $\begin{array}{r}\text { No sense of 'order' to the design - an incoherent and } \\
\text { inharmonious collection of elements }\end{array}$ & 1 & 2 & 3 & 4 & $\begin{array}{l}\text { A high sense of 'order' to the design - a pleasing harmony } \\
\text { of shapes, material, finish, colour and structure }\end{array}$ \\
\hline & $\begin{array}{r}\text { Its appearance is inappropriate and does not make } \\
\text { sense - it just looks wrong! }\end{array}$ & 1 & 2 & 3 & 4 & Its appearance makes complete sense - it just looks right! \\
\hline \multirow{3}{*}{$\begin{array}{l}\text { Symbolism } \\
\text { and status }\end{array}$} & $\begin{array}{r}\text { Ownership has no (or a detrimental) impact on 'status' } \\
\text { amongst the peer group of target market }\end{array}$ & 1 & 2 & 3 & 4 & $\begin{array}{l}\text { Ownership improves 'status' amongst the peer group of } \\
\text { target market }\end{array}$ \\
\hline & $\begin{array}{r}\text { It does not represent or express the tastes or values of } \\
\text { its target market }\end{array}$ & 1 & 2 & 3 & 4 & $\begin{array}{l}\text { It accurately symbolises or expresses the values, beliefs } \\
\text { and tastes of its target audience }\end{array}$ \\
\hline & $\begin{array}{r}\text { Appearance is inappropriate for the context or } \\
\text { environment of use }\end{array}$ & 1 & 2 & 3 & 4 & $\begin{array}{l}\text { Appearance is appropriate for the intended context or } \\
\text { environment of use }\end{array}$ \\
\hline \multirow{3}{*}{ Visual clarity } & $\begin{array}{r}\text { No clear brand identity or coherence across the full } \\
\text { product range }\end{array}$ & 1 & 2 & 3 & 4 & $\begin{array}{l}\text { Design reinforces and reflects the company's brand values } \\
\text { and identity }\end{array}$ \\
\hline & $\begin{array}{r}\text { Appearance is inconsistent with expected values - e.g. } \\
\text { tough, precious, fun etc }\end{array}$ & 1 & 2 & 3 & 4 & $\begin{array}{l}\text { Design expresses and reinforces specific qualities and } \\
\text { values - e.g. fast, accurate, tough etc. }\end{array}$ \\
\hline & $\begin{array}{l}\text { Confusing appearance which gives few clues to } \\
\text { describe the purpose and use of the product }\end{array}$ & 1 & 2 & 3 & 4 & $\begin{array}{l}\text { Appearance helps to clearly describe the product purpose, } \\
\text { function and operation }\end{array}$ \\
\hline All senses & $\begin{array}{r}\text { Feels, smells or sounds horrible - little sensory } \\
\text { pleasure (touch, feel etc) }\end{array}$ & 1 & 2 & 3 & 4 & $\begin{array}{l}\text { Feels as good as it looks: Sensual pleasure through } \\
\text { comfort, material or texture }\end{array}$ \\
\hline Pride & $\begin{array}{r}\text { Little pride of ownership, design is utilitarian and } \\
\text { functional - it gets hidden away }\end{array}$ & 1 & 2 & 3 & 4 & $\begin{array}{l}\text { Design inspires a sense of pride in buying and owning - it } \\
\text { may even go on display }\end{array}$ \\
\hline \multirow[t]{2}{*}{$\begin{array}{l}\text { Emotional } \\
\text { response }\end{array}$} & $\begin{array}{l}\text { Product produces a negative emotional response - it } \\
\text { makes me feel cross, frustrated, angry, upset etc. }\end{array}$ & 1 & 2 & 3 & 4 & $\begin{array}{l}\text { Product produces a positive emotional response - it makes } \\
\text { me feel happy, satisfied, reassured etc. }\end{array}$ \\
\hline & Overall low desirability & 1 & 2 & 3 & 4 & Overall high desirability \\
\hline
\end{tabular}




\section{Producibility ...}

\begin{tabular}{|c|c|c|c|c|c|c|}
\hline Issue & Poor performance & \multicolumn{4}{|c|}{ Score (1-4) } & Great performance \\
\hline \multirow{3}{*}{$\begin{array}{l}\text { Component } \\
\text { manufacture }\end{array}$} & Too many parts - over engineered & 1 & 2 & 3 & 4 & $\begin{array}{l}\text { Optimum (minimum) number of parts - each 'explains' its } \\
\text { reason for being there }\end{array}$ \\
\hline & $\begin{array}{l}\text { Several 'critical' components which are difficult to } \\
\text { produce - lots of scrap and rework }\end{array}$ & 1 & 2 & 3 & 4 & $\begin{array}{l}\text { No 'critical' components and hence little scrap or rework - } \\
\text { all components simple to produce }\end{array}$ \\
\hline & $\begin{array}{r}\text { New components added without considering reusing } \\
\text { existing ones }\end{array}$ & 1 & 2 & 3 & 4 & $\begin{array}{l}\text { No new components added without first considering } \\
\text { reusing existing ones }\end{array}$ \\
\hline \multirow{8}{*}{$\begin{array}{l}\text { Assembly } \\
\text { and test }\end{array}$} & Assembly requires highly skilled staff - 'a black art' & 1 & 2 & 3 & 4 & Simple assembly with minimum training \\
\hline & Extensive testing required & 1 & 2 & 3 & 4 & Designed to minimise the need for testing in production \\
\hline & Too many fasteners - different types and sizes & 1 & 2 & 3 & 4 & Few fasteners - all clearly justified \\
\hline & Specialist assembly and test equipment needed & 1 & 2 & 3 & 4 & Minimum tooling needed with few (if any) specialist tools \\
\hline & $\begin{array}{r}\text { Assembly from many directions, with poor access for } \\
\text { inserting and fixing }\end{array}$ & 1 & 2 & 3 & 4 & $\begin{array}{l}\text { Simple assembly from a single direction (above preferably) } \\
\text { with open access }\end{array}$ \\
\hline & $\begin{array}{l}\text { Several 'tricky to handle' components (large, small, } \\
\text { tangle, flexible, nesting etc.) }\end{array}$ & 1 & 2 & 3 & 4 & No component handling difficulties \\
\hline & A confusing mess of wires and cables & 1 & 2 & 3 & 4 & $\begin{array}{l}\text { Cables \& wires minimised - and simply organised when } \\
\text { needed }\end{array}$ \\
\hline & Lots of setting \& adjustment needed & 1 & 2 & 3 & 4 & Designed to minimise the need for setting \& adjustment \\
\hline \multirow[t]{2}{*}{$\begin{array}{l}\text { Platform } \\
\text { strategy }\end{array}$} & $\begin{array}{l}\text { No product platform strategy, with each product using } \\
\text { different modules, components and production methods }\end{array}$ & 1 & 2 & 3 & 4 & $\begin{array}{l}\text { Defined product platforms with a high level of module, } \\
\text { component and process reuse across products }\end{array}$ \\
\hline & Overall poor producibility & 1 & 2 & 3 & 4 & Overall good producibility \\
\hline
\end{tabular}

Novelty \& differentiation ...

\begin{tabular}{|c|c|c|c|c|c|c|}
\hline \multirow{2}{*}{$\begin{array}{c}\text { Issue } \\
\text { Core benefits }\end{array}$} & \multirow{2}{*}{$\begin{array}{r}\text { Poor performance } \\
\text { No clear differentiation - generic product with standard } \\
\text { features }\end{array}$} & \multicolumn{4}{|c|}{ Score (1-4) } & \multirow{2}{*}{$\begin{array}{l}\text { Great performance } \\
\text { Clearly differentiated offering - unique benefits to owning or } \\
\text { using }\end{array}$} \\
\hline & & 1 & 2 & 3 & 4 & \\
\hline $\begin{array}{l}\text { Functions \& } \\
\text { features }\end{array}$ & "Me-too" product - standard features at a standard price & 1 & 2 & 3 & 4 & $\begin{array}{l}\text { Radical solution that addresses the 'problem' in new and } \\
\text { interesting ways }\end{array}$ \\
\hline Technology & Yesterday's technology - not a differentiator & 1 & 2 & 3 & 4 & $\begin{array}{l}\text { Novel / disruptive technology - innovative \& will change the } \\
\text { market - a key differentiator }\end{array}$ \\
\hline $\begin{array}{l}\text { Technical } \\
\text { quality }\end{array}$ & $\begin{array}{l}\text { Engineering quality offers no differentiation - } \\
\text { robustness, reliability or serviceability etc. }\end{array}$ & 1 & 2 & 3 & 4 & $\begin{array}{l}\text { Engineering quality a key differentiator - robustness, } \\
\text { reliability or serviceability etc. }\end{array}$ \\
\hline Aesthetics & Visually average - not a differentiator & 1 & 2 & 3 & 4 & Novel aesthetics - a key differentiator \\
\hline Usability & $\begin{array}{r}\text { Standard user interface and controls - not a } \\
\text { differentiator }\end{array}$ & 1 & 2 & 3 & 4 & Highly usable \& inclusive - a key differentiator \\
\hline Brand & Low brand 'equity' - not a differentiator & 1 & 2 & 3 & 4 & Strong \& original brand presence - a key differentiator \\
\hline $\begin{array}{l}\text { After sales } \\
\text { support }\end{array}$ & $\begin{array}{r}\text { Training, service, support and maintenance not a } \\
\text { differentiator }\end{array}$ & 1 & 2 & 3 & 4 & $\begin{array}{l}\text { After sales support offers unique differentiation (service, } \\
\text { maintenance, training etc) }\end{array}$ \\
\hline $\begin{array}{l}\text { Finance \& } \\
\text { warranty }\end{array}$ & No differentiation through financing or warranties & 1 & 2 & 3 & 4 & $\begin{array}{l}\text { Novel finance or warranty arrangements provide clear } \\
\text { differentiation }\end{array}$ \\
\hline Delivery & No differentiation through delivery & 1 & 2 & 3 & 4 & Delivery capability offers real differentiation \\
\hline \multirow{3}{*}{$\begin{array}{c}\text { Other } \\
\text { qualities } \\
\text { (name them) }\end{array}$} & No differentiation or novelty & 1 & 2 & 3 & 4 & Novel approach / a key differentiator \\
\hline & No differentiation or novelty & 1 & 2 & 3 & 4 & Novel approach / a key differentiator \\
\hline & No differentiation or novelty & 1 & 2 & 3 & 4 & Novel approach / a key differentiator \\
\hline & Overall poor novelty \& differentiation & 1 & 2 & 3 & 4 & Overall good novelty \&differentiation \\
\hline
\end{tabular}




\title{
AUTHOR INFORMATION
}

\section{Dr James MOULTRIE}

\author{
Institute for Manufacturing, University of Cambridge, Mill Lane, Cambridge, CB2 1RX, UK, \\ jm329@eng.cam.ac.uk
}

James Moultrie research interests are in the area of product design, new product development inbound-marketing and design management. He is a Chartered Mechanical Engineer (IMechE) and has experience as a product marketing manager, project manager and senior engineer in the precision instruments sector. In 2000 he was awarded a 'Scientific and Technical Academy Award' and an Emmy for work on a range of lenses for professional cinematography.

\section{Professor P John CLARKSON}

Head of the Engineering Design Centre, Department of Engineering, University of Cambridge

John Clarkson's research interests are in the general area of engineering design, particularly the development of design methodologies to address specific design issues, for example, complex systems design, medical equipment design, inclusive design and the use of knowledge-based systems in design. As well as publishing over 250 papers in the past ten years he has written a number of books on medical equipment design and inclusive design. Prior to his academic career, he had a wide range of product development experience, with a focus on medical equipment design and training simulation for the Ministry of Defence.

\section{David PROBERT}

Head of the Centre for Technology Management, Institute for Manufacturing, Department of Engineering, University of Cambridge

David Probert is a founding member and Head of the Centre for Technology Management within the Institute for Manufacturing at the University of Cambridge. His research interests span the field of technology management from technology acquisition to exploitation. He has significant industrial experience covering a wide range of industrial engineering and management disciplines in the UK and overseas. 